\title{
THE ARTERIAL VASCULARIZATION OF THE AMYGDALA IN DOGS
}

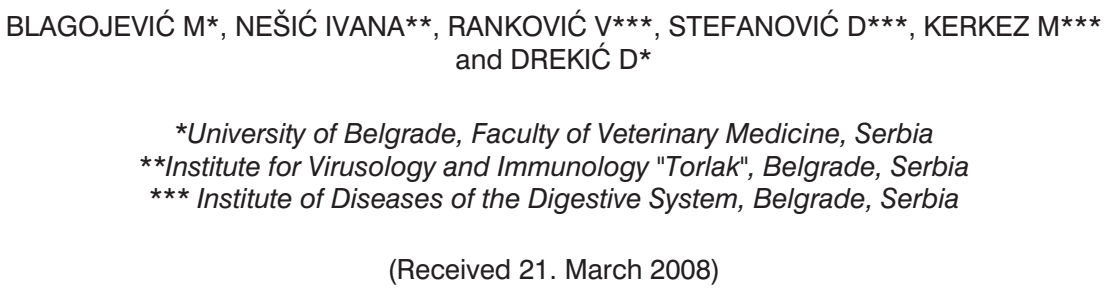

We investigated the vascularization of the amygdala of the dog using various contrast agents injected into the internal carotid and vertebral artery. Subsequent clearance of the tissues gives us an opportunity to study the finest capillary network in the amygdala.

The corticomedial part of the amygdala has a good vascularization given by the rostral and caudal choroid arteries. The rostral choroid gives off a rich capillary net to the nucleus centralis (NCE), its pars lateralis (NCE $)$ and pars medialis $\left(N C E_{M}\right)$. Nucleus medialis (NM) is poorly vascularized compared to the central nuclei. The massa intercalata (MI) also has a delicate artery around which there is a fine net of capillaries. Nucleus corticalis (NCO) and area enthorhinalis (AER) are better vascularized by the subpial blood vessel. The caudal choroid, a branch of the caudal cerebral artery is a source of subpial capillaries.

The basolateral part of the amygdala is very well vascularized by the rostral choroid artery, a branch of the middle cerebral, especially the nucleus basolateralis (NBL) and nucleus lateralis posterior (NLP). The nucleus basomedialis (NBM) is poorly vascularize by the rostral choroid artery .

The amygdala, is served by the middle cerebral artery, via its branch, the rostral choroid, and the caudal cerebral artery via its branch the caudal choroid artery.

Every amygdala nucleus has its own central artery around which is formed a rich net of capillaries.

Key words: dog, amygdala, arteries, nuclei of the amygdala, massa intercalata, area enthorhinalis.

\section{INTRODUCTION}

There is a variety of methods used for examining the vascularization of organs and other parts of the body. They include, in the first place, injecting of blood vessels with different substances and then monitoring their course by 
making specimens, tissue clearing, X-raying, making casts, etc. (Swindle, 1956; Carleton, et a.l, 1957; Hughes, 1965; Hildebrand, 1968; Popovic and Champo, et a.I, 1974; Popovic, 1977; Drekic,1979).

The arterial system of animals has been studied by many authors. This includes the circulatory system of domestic mammals (Miller et al.,1964;; Ellenberger and Baum 1974; Sisson et al., 1975; Nickel et al., 1981; Jankovic et al., 1988), the arteries of the small green monkey (Blagojevic et al., 1989, 1999, 1998, 2004; Nikolic et al., 2003.), the subclavian artery and its branches in the ground squirrel (Nikolic et al., 2004), the arterial circulation of the limbic structures in the guinea pig (Librizzi et al., 1999) and morphology of the amygdala nuclei of the rat (Drekic et al., 1995a, 1995b, 2002).

The available literature offers very little information on the arteries which supply the amygdala of the dog. Librizzi et al. (1999) investigated the vascular territories of the cerebral arteries that originate from the Willis circle to supply limbic structures in the guinea pig brain. Drekic et al. (1995a; 1995b) have studied different neuronal cell groups in corticomedial and basolateral amygdala in male and female rats, but did not investigate the vascularization of these parts of the amygdala. This was the reason we undertook these studies of the amygdala nuclei and its arteries in the dog which were then compared with the corresponding arteries in other domestic mammals (Sisson et al., 1975; Jankovic et al., 1988), small green monkey (Blagojevic et al., 2004; Blagojevic et al., 1999; Blagojevic et al., 1998; Teofilovski, 1982; Stanojevic et al., 1983), guinea pig (Librizzi et al., 1999) and ground squirrel (Nikolic et al., 2004).

\section{MATERIALS AND METHODS}

A study of the vascularisation of the amygdala in the dog was carried out on 10 adult animals, of both sexes. Two methods were implemented: injection of various contrast agents and Splteholtzat's method. The most frequently used substances for injection into the internal carotid artery, were gelatin-ink, gelatinminium and latex-ink. Spalteholtz method used for clearing the tissue gives us an opportunity to study a fine net of capillaries in the amygdala.

In order to study the threedimensional aspect of the amygdala of blood vessels, as well as its relationship to various structures visible on the preparation, specimens about $50 \mu \mathrm{m}$ thick were made.

The blood vessels of the amygdala were observed in depth by raising and lowering the microscope tube.

A stereo-microscope SM XX and Universal Research Microscope NU 2 Carl Zeiss Jena were used for observing and photographing the specimens.

\section{RESULTS AND DISCUSSION}

The tissues become fully transparent during the clearing process and their structure is impossible to be recognized. Only the outlines of the preparation, taken as a whole, can be seen. The blood vessels can be examined in depth to a 
great extent by raising or lowering the microscope tube (Swindle, 1956; Carleton et al., 1957; Hughes, 1965; Hildebrand, 1968; Champo et al., 1974; Popovic, 1977; Popovic et al.,1979).

The internal carotid and vertebral arteries in the dog, as well as in other domestic mammals (Sisson et al., 1975; Jankovic et al., 1988; Nickel et al., 1981; Baum, 1974), small green monkey (Blagojevic et al., 2004) guinea pig (Popesko, 1992; Librizzi et al., 1999) are the largest sources of blood to the brain of these animals. However, the arterial blood of the ground squirrel (Nikolic et al., 2004) is brought to the brain exclusively by the vertebral artery.

Both internal carotid ( $A$. carotis interna sinistra et $A$. carotis interna dextra) of the dog runs through the pharyngeal space towards the cranial cavity, which they enter after passing through the carotid canals (canales carotici) in the petrosa of the temporal bone into the cavernous sinus, where both internal carotides are joined via the $A$. intercarotica caudalis. Inside the cavernous sinus the Aa. carotides internae run rostrally, lateral to the hypophysis and then perforate the dura mater as the cerebral carotid artery (a. carotis cerebralis). On entering in the subarachnoidal space the vessel trifurcates, as the middle cerebral, rostral cerebral and caudal communicating arteries in the dog, and as ophtalmic, middle cerebral and caudal communicating arteries in the small green monkey (Blagojevic, 2004; Teofilovski et al., 1984).

The caudal communicating artery (a. communicans caudalis) is the weakest branch of the internal carotid artery in the dog and small green monkey (Blagojevic et al., 2004). It runs aborally and connects the internal carotid and basilar arteries and forms the caudolateral quadrant of the Circulus arteriosus cerebri (Nomina Anatomica, 1973). The caudal cerebral artery is the terminal branch of the basilar artery in the dog or one of the branch of the caudal communicating (Jankovic et al., 1991) . It runs to the cerebral peduncle crossing its ventral side and than reverses to the dorsal side of the peduncle. It gives off the caudal choroid artery which runs along the choroid plexus towards the interventricular foramen. A rich capillary network is found in the ventral part of the hippocampus, enthorhinal area and cortical nuclei (Figure 2A).

The middle cerebral artery (a. cerebri media, Figure $2 \mathrm{~A}$ ) is the largest branch of the internal carotid artery which supplies the brain of the dog and other domestic mammals (Miller et al., 1964; Jankovic at al., 1988), rodents (Popesko et al., 1992; Librizzi et al., 1999; Nikolic et al., 2004) and small green monkey (Blagojevic et al., 2004). However, Jankovic, et al., 1991. have described the middle cerbral artery as the branch of the cerebral carotid or communication arteries. The middle cerebral artery in the dog leaves the internal carotid as a terminal branch, about $1 \mathrm{~mm}$ from the origin of the caudal communication. At its beginning the middle cerebral artery gives off the rostral choroid artery similar to other domestic animals (Sisson et Grossman, 1975) and than it lies on the anterior perforated substance. The rostral choroid runs along the optic tract, penetrating the lateral ventricle and suplies its walls and vessels of the chorioid plexus (Figure 1B). The rostral choroid sends branches to the amygdala, gives off central arteries wich enter through the nuclei of the amygdala, branching into a fine net of capilaries around the nuclei of the corticomedial and basolateral part of the 
amygdala (Figure 2,3). There is a rich net of capillaries of the corticomedial part of the amygdala about the central nuclei (NCE) and its medial and lateral part (NCE and $N_{C} E_{L}$, Figure 2A) similarly to the guinea pig (Librizzi et al., 1999). The Massa intercalata (MI) has a good vascularization, as well (Figure 3B). The medial nuclei (NM) is poorly vascularized, compared to the central nuclei (Figure $2 A$ ). The cortical nuclei (NCO) and enthorhinal area (AER) are vascularised by the subpial blood vessels (figure 2A). The caudal choroid artery is a source of subpial capillaries. Basolateral part of the amygdala is very well vascularized, especially basolateral (NBL), posterior lateral (NLP) and basomedial nuclei (NBM, Figure 2A).

The middle cerebral artery than divides into the cortical and central branches. The terminal cortical branches (rami corticales), in the form of minute twigs, enter the cortex of the lateral surface of the cerebral hemisphere and richly supply it. The central branches (rami centrales) leave the middle cerebral artery near its origin in the form of a large number of small branches which pass through the "perforate substantia" and supply the basal nuclei and adjacent tracts. The amygdaloid body is customarily listed with the basal nuclei for morphological reasons. On the basis of its connections it may be included among the structures of the rhinencephalon (Drekic, 1983).

The caudal cerebral artery of the dog is the terminal branch of the basilar artery, but in some cases it is a branch of the caudal communication (Jankovic et al., 1991). It runs to the cerebral peduncle crossing its ventral side and than reverses to the dorsal side of the peduncle. In this spot it gives off the caudal choroid artery (a. choroidea caudalis) which runs along the choroid plexus towards the interventricular foramen. A rich capillary network is found in the ventral part of the hippocampus, enthorhinal area and cortical nuclei (Figure 2A). Ventral, temporal, part of the hippocampus in the guinea pig (Librizzi et al., 1999) is served exclusively by the rostral posterior cerebral artery similarly to other rodents (Popesko, 1992).

Acording to our investigations, as well as results of other authors (Librizzi et al., 1999; Drekic et al., 2002; Nikolic et al., 2004) the main suppliers of blood to the basolateral and corticomedial part of the amygdala, exept NCO, in the dog is the rostral choroid artery and the branches of the middle cerebral artery. However, the cortical nuclei, hippocampus and enthorhinal area are served exclusively by the caudal choroid, a branch of the caudal cerebral artery.

The rostral cerebral artery (a. cerebri rostralis) originates directly from the internal carotid artery in the dog and other domestic mammals (Nomina Anatomica Veterinaria, 1973), but in the small green monkey it represents the continuation of the internal carotid artery (Blagojevic et al., 2004). It arises lateral to the optic nerve and runs dorsal to the optic nerve. On reaching the longitudinal fissure it unites with its fellow, after which the two vessels separate. In some specimens the rostral communicating artery (a. communicans rostralis) connects both rostral cerebral arteries (a. cerebri rostralis dextra et sinistra) just rostral to the optic chiasma (Nomina Anatomica Veterinaria, 1973). The rostral cerebral artery forms the rostrolateral quadrant of the Circulus arteriosus cerebri (Miller et al., 1964). The rostral cerebral artery sends also central branches (rami centrales) into 
the medullary substance of the hemisphere in the dog, mammals (Nomina Anatomica Veterinaria, 1973) and small green monkey (Blagojevic et al., 2004).

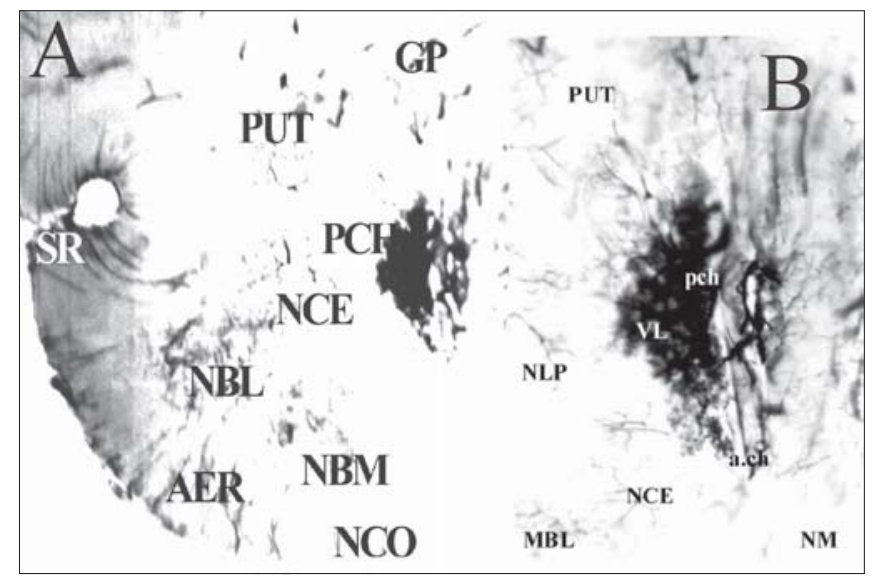

Figure 1. Rostral part of the amygdala nuclei of the dog investigated with gelatin-ink method

Panel A. NCO (cortical nuclei), NBM (basomedial nuclei), NBL (basolateral nuclei), NCE (central nuclei), AER (enthorhinal area), pch (choroid plexus), PUT (putamen), GP (palidal globus), SR (rhinal sulcus) X 120

Panel B. NM (medial nuclei), NLP (lateral posterior nuclei), a. ch (choroide artery), VL (lateral ventricul) X 300

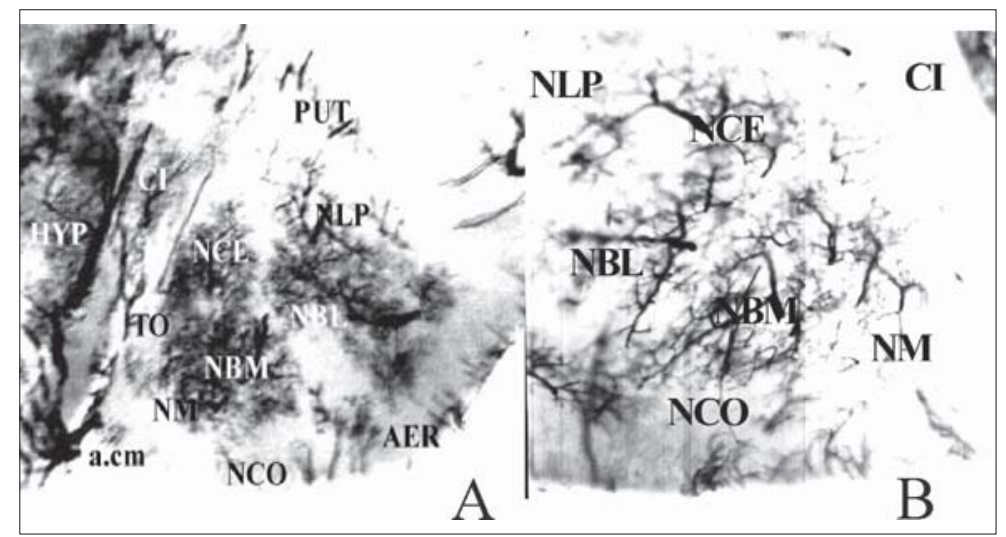

Figure 2. Coronal section of the amygdala dog investigated with gelatin-ink method

Panel A. a. cm (the middle cerebral artery), TO (optic tract), $\mathrm{Cl}$ (internal capsula), HYP (hypothalamus), NCO (cortical nuclei), NBM (basomedial nuclei), NBL (basolateral nuclei), NCE (central nuclei), AER (enthorhinal area), PUT (putamen) X 300

Panel B. NCO (cortical nuclei), NBM (basomedial nuclei), NBL (basolateral nuclei), NCE (central nuclei) 


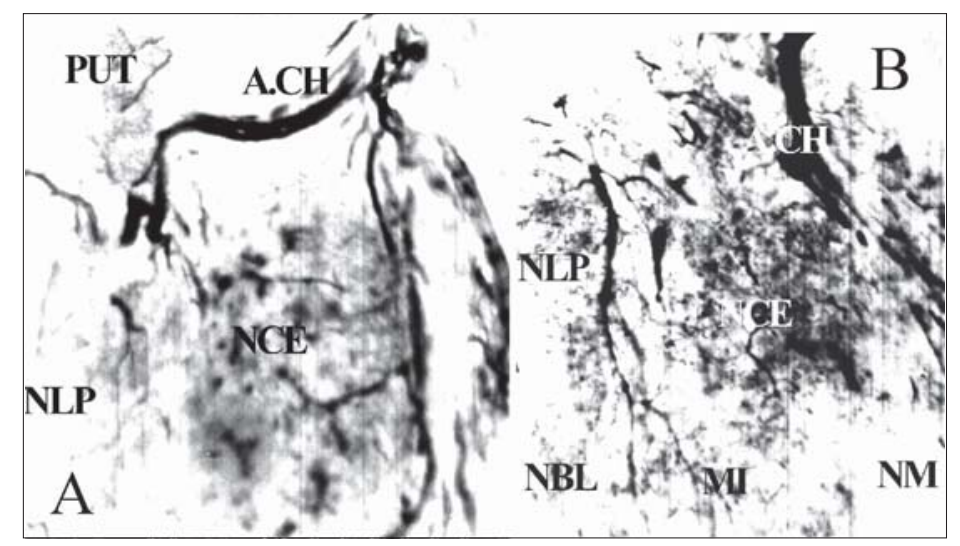

Figure 3. Coronal section of the central nuclei of the amygdala of the dog investigated with gelatin-ink method

Panel A. NCE (central nuclei), NLP (lateral posterior nuclei), PUT (putamen), A.CH (rostral choroid artery), X 300

Panel B. NCE (central nuclei), NLP (lateral posterior nuclei), A. CH (rostral choropid artery) $\mathrm{X} 300$

The internal ophtalmic and internal ethmoidal arteries are smaller arteries which leave the rostral cerebral artery in the dog and other domestic mammals (Nomina Anatomica Veterinaria 1973). However, Jankovic et al. (1991) have designated the rostral chorioid and internal ophtalmic arteries as the branches of the rostral cerebral artery in the dog and other domestic mammals.

The amygdaloid body of the rat was previously referred to in the description of the basal nuclei (Drekic, 1983). Several nuclei of the amygdaloid complex of the rat receive fibers from the olfactory bulbs and the anterior commissure (Drekic, 1983). There are also connections with the septal area by way of the diagonal band. The main efferent pathway is a clearly defined fiber bundle, the stria terminalis.

The stria terminalis in the dog and rat (Drekic, 1983) arises from the rostral part of the amygdaloid body and runs dorsal and caudal along the optic tract to the tail of the caudate nucleus. From there the stria terminalis runs rostrally and ventrally in a groove between the caudate nucleus and the thalamus and ends at the base of the brain in the preoptic and hypothalamic region. These regions are supplied with blood by the middle cerebral artery.

Address for correspondence:

Dr Drekic Dmitar

Faculty of Veterinary Medicine, Department of Anatomy

Bulevar oslobođenja 18

11000 Belgrade, Serbia.

e-mail: ddrekic@vet.bg.ac.yu 


\section{REFERENCES}

1. Baum H, Ellenberger W, 1974, Handbuch der vergleichenden Anatomie der Haustiere,18 Auflage, Springer-Verlag, Berlin.

2. Blagojević Z, 1989, Srce i arterije malog zelenog majmuna (Cercopithecus aethiops sabeus), Doktorska disertacija, Beograd.

3. Blagojević Z, Nikolić Zora, Đelić Dijana, Mrvić Verica, Drekić D, Zorić Z and Blagojević M, 2004, Arterial vascularization of the brain of the small green monkey (Cercopithecus aethops sabeus), Acta Veterinaria Beograd, 54, 319-24.

4. Carleton, HM, Drury RA, 1957, Histological Technique, London, Oxford University Press, New York, Toronto.

5. Champo $\mathrm{CH}$, Steffenhagen WP, Ginter O J, 1974, Clearing technique for preparation and photography of anatomic specimens of blood vessels of female genitalia, Am J Vet Res 35, 30310.

6. Drekić D, 1983, Amigdale i polni steroidi, Doktorska disertacija, Beograd.

7. Drekic D, Malobabic S, Gledic D, Cvetkovic D, 1995a, Different neuronal and glial cell groups in corticomedial amygdala react differently to neonatally administered estrogen, Neurosci, 66, 457-81.

8. Drekic D, Malobabic S, Štimec B, Cvetkovic D, Lozanče O, 1995b, Study of neurons and glial cells of basolateral amygdala in male and female rats neonatally treated with estrogen, Int J Neurosci, 83, 145-51.

9. Hildebrand M, 1968, Anatomical preparations, University of California Press, Berkeley and Los Angeles.

10. Hugh, T, 1965, The preparation of injected and cleared "Whole mounts" for the study of topographical anatomy, Anatom Rec, 153, 129-33.

11. Janković Ž, Stanojević D, Miladinović Ž, 1988, Anatomija domaćih životinja sisara, Angiologija, Beograd.

12. Librizzi Laura, Gererdo Biella, Carilo Cimino, Marco De Curtis, 1999, Arterial supply of limbic structures in the guinea pig, J Comp Neurol, 411, 674-82.

13. Malobabic S, Drekic D, Prostran Mirjana, 2002, Autoradiographic topography of estrogen receptors in the amygdala of the male rat, Acta veterinaria 52, 2-3, 107-16, Beograd.

14. Miller M, Christensen DVM, Howard E, 1964, The anatomy of the dog, WB Saunders Company, Philadelphia-London.

15. Nickel R, Schummer A, Seiferle E, 1981, The Anatomy of the Domestic Animals, The circulatory system, the skin, and the cutaneous organs of the domestic mammals, 3 Verlag Paul Parey, Berlin, Hamburg.

16. Nikolić V, Blagojević Z, Malobabić S, Aranđelović A, Mališ M, Teofilovski-Parapid G, Stanković I, 2003, Distribution of the left coronary artery branches in the African green monkey, Acta veterinaria, 53,139-50.

17. Nikolic Z, Djelic D, Blagojevic Z, Mrvic V, Drekic D, Zoric Z, 2004, The subclavian artery and its branches in the ground squirel (Citellus citellus), Acta veterinaria Beograd, 54, 2-3, 227-37.

18. Nomina Anatomica Veterinaria, 1973, Wiena.

19. Popesko P, Rajtova V, and Horlak J, 1992, Anatomy of the small laboratory animals, Volume one: rabbit, guinea pig, Published by Wolfe Publishing Ltd, 1992.

20. Popović and Drekić,1979, A possibility for the study of micromorphology of blood vascular net and surrounding tissue, Acta Veterinaria, Beograd, 29, 237-42.

21. Popović S, 1977, Latex injected blood vessels and glycerol cleared tissues and organ specimens, Acta Veterinaria, , Beograd, 27, 159-163.

22. Sisson S, Grossman JD, 1975, WB Saunders Company, Philadelphia, London.

23. Swindle PF, 1956, Injected vessels in cleared tissues, Anatom Rec, 124, 2, 472. 


\section{ARTERIJSKA VASKULARIZACIJA AMIGDALE PSA}

BLAGOJEVIĆ M, NEŠIĆ IVANA, RANKOVIĆ V, STEFANOVIĆ D, KERKEZ M i DREKIĆ D

\section{SADRŽAJ}

Proučavanje vaskularizacije amigdale psa vršeno je upotrebom različitih kontrasnih sredstava injiciranih u a. carotis interna i a. vertebralis a prosvetljavanje tkiva daje mogućnost da se prouči i najfinija vaskularna mreža u amigdali.

Kortikomedijalni deo amigdale vaskularišu a. choroidea rostralis i a. choroidea caudalis. A. choroidea rostralis, daje bogatu mrežu kapilara u NCE (nucleus centralis) i njegovom lateralnom i medijalnom delu ( $\mathrm{NCE}_{\mathrm{L}}$ i $\left.\mathrm{NCE}_{\mathrm{M}}\right)$. Nucleus medialis (NME) je slabije vaskularisan u poredjenju sa vaskularizacijom NCE. Massa intercalata (MI) je takodje snabdevena bogatom mrežom kapilara. A. choroidea caudalis, kao subpialna arterija, vaskulariše NCO (nucleus corticalis) i AER (area enthorhinalis).

Bazolateralni deo amigdale vaskulariše samo a. choroid rostralis. Bogata mreža kapilara uočava se u NBL (nucleus basolateralis) i NLP (nucleus lateralis posterior) a nešto siromašnija u NBM (nucleus basomedialis).

Krv u amigdalu dovode dve arterije: a. choroidea rostralis, grana od a. cerebri media, i a. choroidea caudalis, grana od a. cerebri caudalis.

Svaki nukleus amigdale ima svoju centralnu arteriju i oko nje jako razvijenu mrežu kapilara. 